\title{
Effect of Ozone and Antioxidants on Wheat and its Pathogen - Bipolaris sorokininana
}

\author{
U. Mina ${ }^{1 *}$, A. Fuloria ${ }^{1}$ and R. Aggarwal ${ }^{2}$ \\ ${ }^{1}$ Centre for Environment Science and Climate Resilient Agriculture, Indian Agricultural Research Institute, \\ New Delhi-110012, India \\ ${ }^{2}$ Division of Plant Pathology, Indian Agricultural Research Institute, New Delhi-110012, India
}

(Received 8 January 2016; Accepted 8 June 2016;

Communicated by J. Kolmer)

\begin{abstract}
Tropospheric ozone $\left(\mathrm{O}_{3}\right)$ adversely affects growth and productivity of crops and also influences crop-pathogen interactions. Adverse effects of $\mathrm{O}_{3}$ on crops can be mitigated by antioxidants application. In the present study through lab and field experiments impact of $\mathrm{O}_{3}$ and antioxidants treatment to wheat was assessed on growth of Bipolaris sorokiniana (BS-75 strain) pathogen responsible for Spot blotch disease, pathogenesis related (PR) proteins and chitinase content. Results showed that growth of Bipolaris was significantly higher in elevated ozone $\left(\mathrm{EO}_{3}\right)$ exposed plants as compared to control plants. Antioxidants - ascorbic acid (AA), tagetes extract (T) and quercetin (Q) application on culture media and wheat plants, respectively, retarded the growth of Bipolaris sorokiniana. Among the three antioxidants minimum growth of Bipolaris was observed in AA-treated plants as compared to control plants. Reduction in chitinase activity and $\mathrm{PR}$ proteins content due to $\mathrm{EO}_{3}$ treatment in wheat plants was $18 \%$ and $78 \%$, respectively, as compared to control plants. Increase in chitinase activity and PR proteins content due to antioxidants treatment in wheat plants was $45 \%$ and $60 \%$, respectively, as compared to control plants.
\end{abstract}

Keywords: ozone, wheat, pathogen, Bipolaris sorokiniana

\section{Introduction}

Tropospheric ozone $\left(\mathrm{O}_{3}\right)$ a secondary air pollutant, negatively affects agricultural crops and vegetation (Holland et al. 2006; Fuhrer 2009; IPCC 2013). In India also phytotoxic impact of $\mathrm{O}_{3}$ on growth and yield of several crops were reported (Mina et al. 2010; Ghude et al. 2014). Besides the direct adverse effects of $\mathrm{O}_{3}$ on crops, indirectly it alters the interaction between crops and its pest/pathogens (Manning and von Tiedemann 1995; Elad and Pertot 2014). Wheat (Triticum aestivum L.) is a staple food crop of India and its spot blotch disease caused by Bipolaris sorokiniana responsible for up to $22 \%$ and $10-50 \%$ yield losses in warm and humid regions of the world and India, respectively (Saari 1998; Chowdhury et al. 2013). Several reviews have extensively covered possible effects of elevated $\mathrm{O}_{3}$ on future severity of plant diseases (Manning and von Tiedemann 1995; Elad

*Corresponding author; E-mail: usha_env@iari.res.in; Phone: 01125841866 ext. 4798; Fax: 91-011-25841866 
and Pertot 2014; Mikkelsen et al. 2015). Alteration in pathogenesis potential of pathogen due to $\mathrm{O}_{3}$ exposure is of ecological and economical importance. Reports from India on response of $\mathrm{O}_{3}$ predisposed wheat crop to any pathogens are completely lacking.

Adverse effects of $\mathrm{O}_{3}$ on crops can be mitigated through application of $\mathrm{O}_{3}$ protectants containing synthetic or natural antioxidants (Puckette et al. 2008). Among antioxidants, natural antioxidants were preferred more than synthetic antioxidants for mitigating $\mathrm{O}_{3}$ stress effect because of their environmental safety features. Application of antioxidants on crops to protect them from $\mathrm{O}_{3}$ adverse impact may also affect their interaction with its pathogen, which was not monitored yet. The objective of this study was to examine effect of $\mathrm{O}_{3}$ and antioxidants, namely ascorbic acid (AA), quercetin (Q) and tagetes leaves extract $(\mathrm{T})$, on growth of Bipolaris sorokiniana (BS-75 strain), severity of blotch disease and defence response of wheat plants through lab and field experiments.

\section{Materials and Methods}

\section{Experiment location}

Experiments were conducted at the research field and laboratory of Indian Agriculture Research Institute (IARI, $28^{\circ} 35^{\prime}$ N, $77^{\circ} 12^{\prime}$ E), New Delhi during rabi season of $2011-$ 2012 and 2012-2013.

\section{$\mathrm{O}_{3}$ and antioxidants pretreatment to wheat}

Wheat (Triticum aestivum L.) cv. PBW343 was sown in pots on 12 December 2011 and 15 December 2012 by following recommended standard practices. One set of wheat plants were pretreated with different $\mathrm{O}_{3}$ levels (Table 1) in open top chambers (OTCs; $90 \times 120 \mathrm{~cm}$ dimension, made of transparent sheet and installed in open field) for 8 hours per day from seedling to 65-day-old stage. $\mathrm{O}_{3}$ in OTCs was supplied by $\mathrm{O}_{3}$ generator (Standard Appliances, Varanasi, India). $\mathrm{O}_{3}$ concentration in OTCs was monitored with an online ozone analyzer. Plant leaves were monitored regularly for $\mathrm{O}_{3}$ injury. Another set of wheat plants, since five, leaf stage were treated by $1 \%$ AA, $10 \%$ T and $500 \mathrm{ppm}$ Q, respectively, at 15 days interval till 65-day-old stage in OTCs supplied with NF air. Control wheat plants were not given any antioxidant treatment.

Table 1. Ozone levels maintained in OTCs to expose wheat plants

\begin{tabular}{|l|c|l|}
\hline \multicolumn{1}{|c|}{ Treatment } & Abbreviated as & \multicolumn{1}{c|}{$\mathrm{O}_{3}$ concentration } \\
\hline Ambient $\mathrm{O}_{3}^{*}$ & $\mathrm{AO}_{3}$ & $12-72 \mathrm{ppb}$ \\
\hline Non-filtered air** & $\mathrm{NF}$ & $5-10 \%$ lower than ambient $\mathrm{O}_{3}$ \\
\hline Elevated level $\mathrm{O}_{3}$ & $\mathrm{EO}_{3}$ & ambient $\mathrm{O}_{3}+25-30 \mathrm{ppb}$ \\
\hline Charcoal filtered air & $\mathrm{CF}$ & $65-70 \%$ lower than ambient $\mathrm{O}_{3}$ \\
\hline
\end{tabular}

*Plants were exposed to ambient/naturally prevailing levels of ozone outside OTC.

**Plants were exposed to ambient air without filtration inside OTC. 
Bipolaris sorokiniana inoculum

Isolate BS-75 of Bipolaris sorokiniana (Sacc.) Shoem., procured from the Department of Plant Pathology of the IARI, New Delhi (India) was used in the study. Mycelium was grown on potato dextrose agar (PDA, Sigma) for 3 weeks at $25^{\circ} \mathrm{C}$ in the dark. Conidia and hyphae were scraped off from medium with spatula and mixed with sterile distilled water. Conidial suspensions filtered through cheesecloth to eliminate mycelial fragments. Inoculum densities were adjusted to $2-2.5 \times 10^{3}$ conidia/ $\mathrm{ml}$.

\section{Bipolaris growth on antioxidants supplemented culture media}

A $3 \mathrm{~mm}$ diameter disc of 15-day-old culture of Bipolaris sorokiniana (strain BS-75) was cultured at $25^{\circ} \mathrm{C}$ in replicates on Petri dishes of $90 \mathrm{~mm}$ diameter containing solidified $15 \mathrm{ml}$ potato dextrose agar (PDA) medium supplemented with antioxidants (Table 2). The plates were observed for colony diameter and sporulation till 7 days incubation period.

\section{Bipolaris growth on $\mathrm{O}_{3}$ and antioxidants pretreated wheat}

After 65 days $\mathrm{O}_{3}$ treatment, on $66^{\text {th }}$ day wheat plants were taken out of the OTCs for Bipolaris inoculation. Six healthy tillers per pot were inoculated in evening before sunset by spraying $15 \mathrm{ml}$ conidial suspension per tiller. Immediately after inoculation plants in each pot were covered with a transparent, needle pricked polythene bag $(0.06 \mathrm{~mm}$ thickness) for 48 hours. The film blocked wind and maintained moisture inside while transmitting long-wave radiation, consequently dew formation on the wheat leaves surface was enhanced. Plants returned to OTC after inoculation and supplied with charcoal filtered air. Bipolaris growth parameters monitored on inoculated plants for 7 days were number of lesions, lesion size, latent period (number of days between inoculation and appearance of first mature conidia), sporulation and spores per $25 \mathrm{~mm}^{2}$.

Table 2. Concentrations of antioxidants supplement in PDA agar

\begin{tabular}{|l|c|c|}
\hline \multicolumn{1}{|c|}{ Antioxidant } & Concentration & Abbreviated as \\
\hline Ascorbic acid & $0.5 \%$ & AA1 \\
\hline Ascorbic acid & $1 \%$ & AA2 \\
\hline Ascorbic acid & $1.5 \%$ & AA3 \\
\hline Quericitin & $250 \mathrm{ppm}$ & Q1 \\
\hline Quericitin & $500 \mathrm{ppm}$ & $\mathrm{Q} 2$ \\
\hline Quericitin & $750 \mathrm{ppm}$ & $\mathrm{Q} 3$ \\
\hline Tagetes leaves extract & $5 \%$ & $\mathrm{~T} 2$ \\
\hline Tagetes leaves extract & $10 \%$ & $\mathrm{~T} 2$ \\
\hline Tagetes leaves extract & $15 \%$ & $\mathrm{~T} 3$ \\
\hline
\end{tabular}




\section{$P R$ protein content and chitinase activity in $\mathrm{O}_{3}$ and antioxidants pretreated and Bipolaris infected wheat}

The colorimetric assay of chitinase activity was carried out according to Morgan and Elson (1934). One enzyme unit (EU) activity is the amount of enzyme which produces $100 \mu \mathrm{g} \mathrm{NAG} / \mathrm{ml}$ chitin solution in $1 \mathrm{~h}$ at $37^{\circ} \mathrm{C}$ at $\mathrm{pH}$ 5.2. The total protein extraction was first done from wheat leaves using total protein extraction kit supplied by G-Biosciences (Cat \# 786-225). From the extracted total protein, PR proteins were quantitatively estimated by using the PR ELISA Kit (Catalog No. E0431 pl) supplied by USCN LIFE. The PR proteins content and chitinase activity were monitored at the end of $\mathrm{O}_{3}$ and antioxidants treatment (i.e. 65 DAS), after 7 days of incubation period in flag leaves of plants with and without Bipolaris pathogen.

\section{Statistical analysis}

Data obtained from the experiments conducted in both years were pooled and subjected to homogeneity test. The pooled data subjected to single factor $\left(\mathrm{O}_{3}\right.$ and antioxidant $)$ analysis of variance (ANOVA) and least-significant differences were calculated at $P \leq 0.05$.

\section{Results}

\section{Environmental conditions}

Ambient $\mathrm{O}_{3}$ levels at the experimental site ranged between 12-72 ppb during wheat crop growing period. Average temperature and average relative humidity at the experimental site during the crop growth period were $20 \pm 2.5^{\circ} \mathrm{C}$ during day, $15 \pm 2.0^{\circ} \mathrm{C}$ at night and $50 \pm 60 \%$, respectively. Ozone injury symptoms on wheat plants were not visible in any treatment, except $\mathrm{EO}_{3} . \mathrm{EO}_{3}$ exposed plants exhibited $8-10 \% \mathrm{O}_{3}$ injury lesions on old leaves.

Table 3. Effect of antioxidants on Bioplaris growth

\begin{tabular}{|l|c|c|c|c|c|c|c|c|c|c|c|c|}
\hline \multicolumn{2}{|c|}{} & C & AA1 & AA2 & AA3 & Q1 & Q2 & Q3 & T1 & T2 & T3 \\
\hline Colony diameter (mm) \\
\hline After 2 days & $0.8^{\mathrm{a}}$ & $0.5^{\mathrm{b}}$ & $0.2^{\mathrm{b}}$ & $0^{\mathrm{b}}$ & $0.7^{\mathrm{b}}$ & $0.6^{\mathrm{b}}$ & $0.3^{\mathrm{b}}$ & $0.2^{\mathrm{b}}$ & $0.3^{\mathrm{b}}$ & $0.5^{\mathrm{b}}$ \\
\hline After 5 days & $6.1^{\mathrm{a}}$ & $1.0^{\mathrm{b}}$ & $0.6^{\mathrm{b}}$ & $0^{\mathrm{b}}$ & $5.7^{\mathrm{a}}$ & $4.3^{\mathrm{b}}$ & $4.6^{\mathrm{b}}$ & $2.9^{\mathrm{b}}$ & $1.7^{\mathrm{b}}$ & $1.6^{\mathrm{b}}$ \\
\hline After 7 days & $8.0^{\mathrm{a}}$ & $1.5^{\mathrm{b}}$ & $0.1^{\mathrm{b}}$ & $0^{\mathrm{b}}$ & $7.8^{\mathrm{a}}$ & $6.9^{\mathrm{a}}$ & $6.0^{\mathrm{b}}$ & $3.9^{\mathrm{b}}$ & $2.5^{\mathrm{b}}$ & $1.9^{\mathrm{b}}$ \\
\hline $\begin{array}{l}\text { Sporulation 7 days } \\
\text { after }\end{array}$ & ++ & - & - & - & ++ & + & + & + & - & - \\
\hline
\end{tabular}

Mean values marked with the different letters are statistically significantly different among treatments ++ number of conidia between $1.5 \times 10^{8}-2.5 \times 10^{8} / \mathrm{ml}$; + number of conidia between $0.5 \times 10^{8}-1.0 \times 10^{8} / \mathrm{ml}$. 
MiNA et al.: Ozone and Antioxidants Effect on Wheat Pathogen

Table 4. ANOVA of $\mathrm{O}_{3}$ and antioxidants effects on Bipolaris growth

\begin{tabular}{|c|c|c|c|c|c|}
\hline Treatment & Growth parameter ${ }^{\mathrm{a}}$ & DF & Replication & F ratio & $\begin{array}{c}\text { Significance } \\
\text { level }^{\mathrm{b}}\end{array}$ \\
\hline \multirow{4}{*}{$\begin{array}{l}\mathrm{O}_{3} \text { pretreatment to } \\
\text { wheat in OTCs }\end{array}$} & No. of lesions & 36 & 10 & 2.6 & $.003 * *$ \\
\hline & Maximum lesion size (mm) & & 10 & 6.5 & $.01 *$ \\
\hline & Latent period & & 10 & 2.5 & $.002 * *$ \\
\hline & Spores $/ 25 \mathrm{~mm}^{2}$ & & 10 & 1.9 & $.001 * * *$ \\
\hline \multirow{4}{*}{$\begin{array}{l}\text { Antioxidants } \\
\text { pretreatment to wheat } \\
\text { in OTCs }\end{array}$} & No. of lesions & 36 & 10 & 3.5 & $.007 *$ \\
\hline & Maximum lesion size (mm) & & 10 & 4.1 & $.005 * *$ \\
\hline & Latent period & & 10 & 1.4 & $.005 * *$ \\
\hline & Spores $/ 25 \mathrm{~mm}^{2}$ & & 10 & 9.8 & $.02 *$ \\
\hline \multirow{2}{*}{$\begin{array}{l}\text { Antioxidants } \\
\text { supplementation } \\
\text { in culture media }\end{array}$} & Colony diameter & 36 & 5 & 5.1 & $.002 * *$ \\
\hline & Sporulation & & 5 & 1.9 & $.01 *$ \\
\hline
\end{tabular}

aThe two uppermost leaves of each plant were evaluated; ${ }^{b}$ Significance levels; $* P<0.05 ; * * P<0.01 ; * * * P<0.001$.
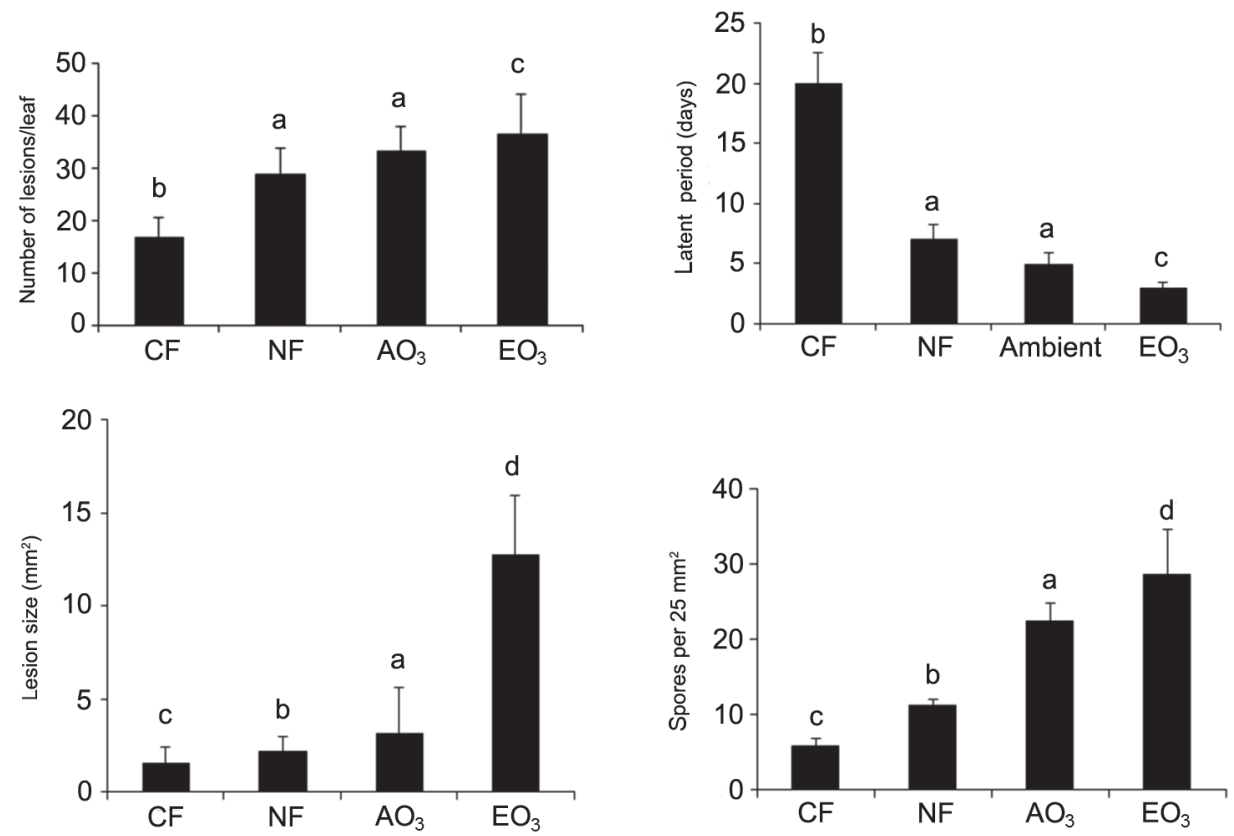

Figure 1. Bipolaris growth on $\mathrm{O}_{3}$ pretreated wheat. Values are means $\pm \mathrm{SE}(\mathrm{n}=10)$. Values marked with the different letters are statistically significantly different among treatments $(P \leq 0.05)$ 

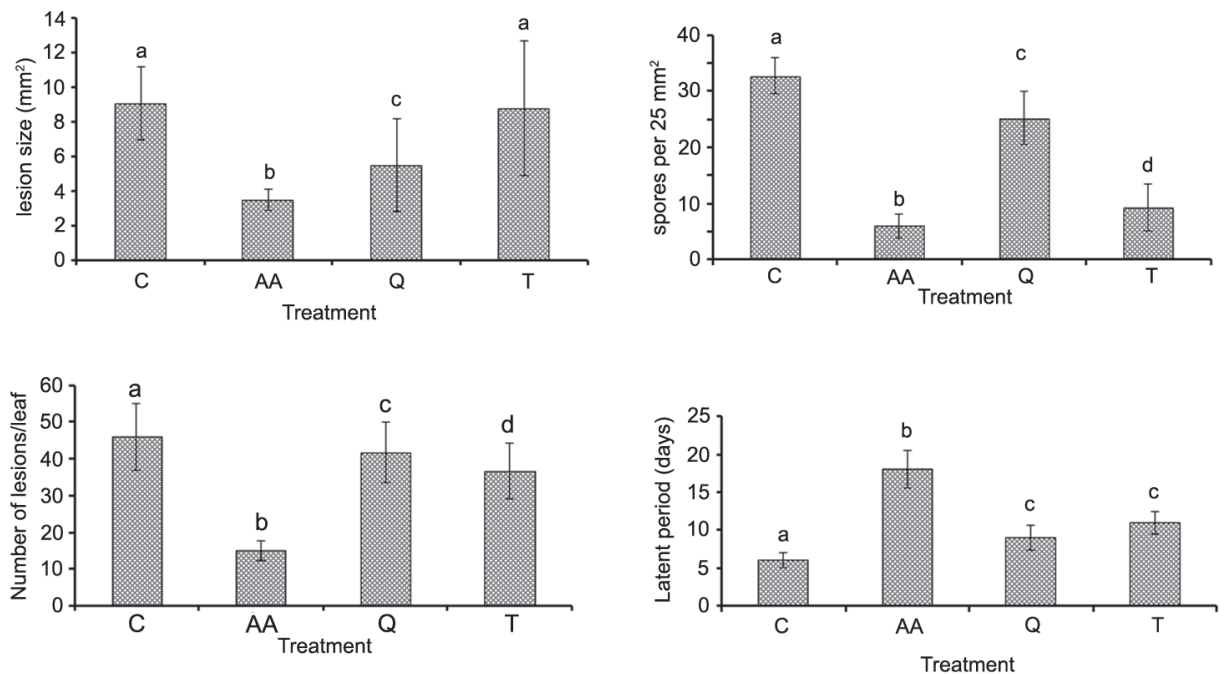

Figure 2. Bipolaris growth on antioxidants pretreated wheat. Values are mean $\pm \mathrm{SE}(\mathrm{n}=10)$. Values marked with the different letters are statistically significantly different $(P \leq 0.05)$

Bipolaris growth on antioxidants supplemented culture media

Antioxidants supplementation significantly affected growth of Bipolaris sorokiniana (Tables 3 and 4). Inverse relationship was observed between the antioxidants concentration and the Bipolaris growth. Among three antioxidants, AA was the most effective inhibitor for the growth of Bipolaris sorokiniana followed by $\mathrm{T}$ and $\mathrm{Q}$, respectively, as compared to the control (Table 3).

\section{Bipolaris growth on $\mathrm{O}_{3}$ and antioxidants pretreated wheat}

Effect of $\mathrm{O}_{3}$ treatments on Bipolaris growth was variable. Lesions/leaf and spores/ $25 \mathrm{~mm}^{2}$ were maximum and minimum on $\mathrm{EO}_{3}$ and $\mathrm{CF}$ treated plants, respectively. Significant differences in Bipolaris lesions size were observed in NF (27\%), $\mathrm{AO}_{3}(50 \%)$ and $\mathrm{EO}_{3}(90 \%)$ treatments as compared to $\mathrm{CF}$ (Table 4, Fig. 1). Shortening of latent period with increasing $\mathrm{O}_{3}$ concentration was observed (Fig. 1). The $50 \%$ of $\mathrm{EO}_{3}, 25 \%$ of $\mathrm{AO}_{3}$ exposed plants exhibited black spots with conidiophores on leaf surface within 7 days and after 10 days of incubation period, respectively. In CF exposed plants, disease symptoms were visible only on one plant after 20 days of incubation.

Bipolaris growth on wheat plants was adversely affected by antioxidants treatment (Table 4, Fig. 2). Among three antioxidants, Bipolaris growth was minimum on AA treated wheat plants followed by $\mathrm{T}$ and $\mathrm{Q}$ as compared to control plants. On AA, Q and T treated plants, spot blotch lesions appeared after 10, 4 and 6 days of incubation, respectively. Number of lesion in AA, Q and T treated wheat plant were $67 \%, 9 \%$ and $22 \%$ less, respectively as compared to control plants. Maximum size of lesion was $67 \%, 38 \%$ and 
$3 \%$ less on AA, Q and T treated wheat plants as compared to control plants. Latent period and Spores $/ 25 \mathrm{~mm}^{2}$ was maximum and minimum on AA treated and control wheat plants, respectively.

\section{$P R$ protein content and chitinase activity in $\mathrm{O}_{3}$ and antioxidants pretreated and Bipolaris infected wheat}

Exposure of $\mathrm{O}_{3}$ significantly affected PR protein content in wheat. $2.74-12.83 \mathrm{ng} / \mathrm{g}$ leaf $\mathrm{PR}$ protein content was observed in $\mathrm{O}_{3}$-treated plants (Fig. 4a). Maximum PR protein content (9.8 ng/g leaf) in CF air plants without pathogen was observed (Fig. 3a). PR protein content (10.1 ng/g leaf) was maximum in AA treated plants and minimum (4 ng/g leaf) in control plants. Among antioxidant treated plants with pathogen and without pathogen, PR protein content was maximum (12.5 ng/g leaf) in AA treated with pathogen plants (Fig. 3b).
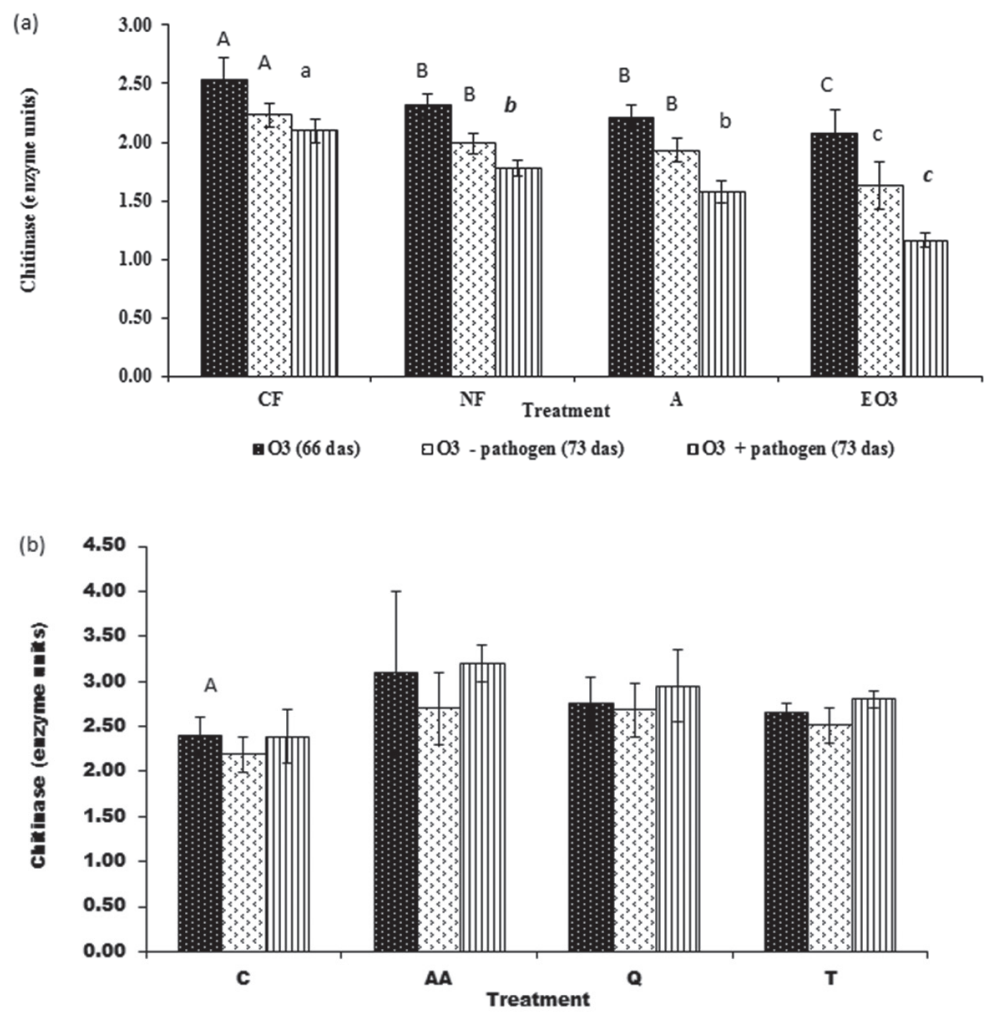

antioxidant (66 das) Đantioxidant -pathogen (73 das) mantioxidant + pathogen (73 das)

Figure 3. PR protein content in wheat plants with and without pathogen (a) pretreated with $\mathrm{O}_{3}$ (b) pretreated with antioxidant. Values are mean $\pm \mathrm{SE}(\mathrm{n}=10)$. Values marked with the different letters are statistically significantly different $(P \leq 0.05)$ 
Chitinase activity in $\mathrm{EO}_{3}$ exposed plants was $27.3 \%$ less than $\mathrm{CF}$ exposed plants. Chitinase activity was significantly less in $\mathrm{O}_{3}$ exposed plants with pathogen as compared to $\mathrm{O}_{3}$ exposed plants without pathogen (Fig. 4a). Enhancement in chitinase activity was observed for wheat plant treated with antioxidants. Maximum (3.1 EU) and minimum (2.2 EU) activity was observed in AA and control plants, respectively. Among antioxidant treated plants with and without pathogen, the chitinase activity was more in antioxidant treated and pathogen infected plants. Plants treated with AA and with disease exhibited maximum (3.2 EU) enzyme activity (Fig. 4b).
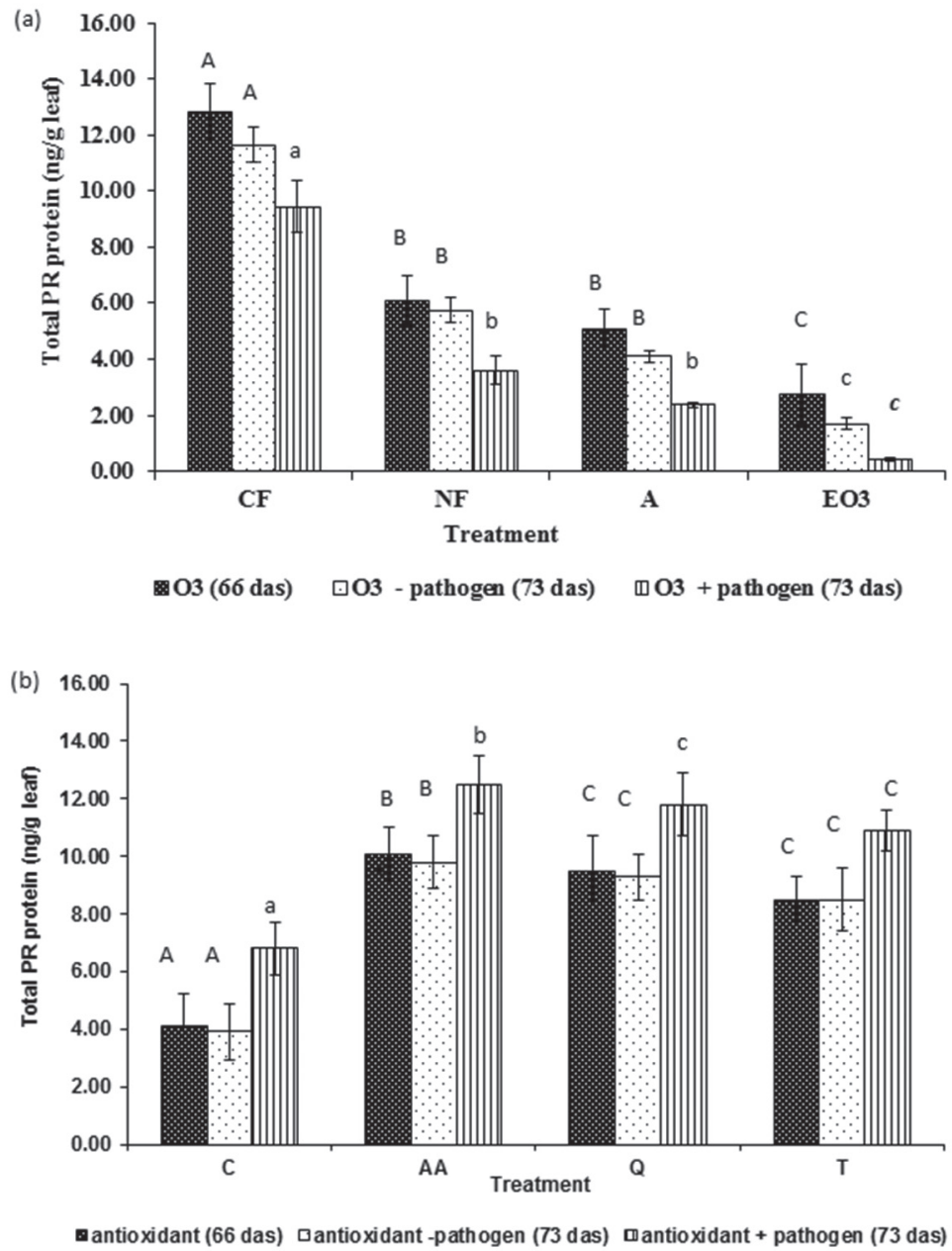

Figure 4. Chitinase activity in wheat plants with and without pathogen (a) pretreated with $\mathrm{O}_{3}(\mathrm{~b})$ pretreated with antioxidant. Values are mean $\pm \mathrm{SE}(\mathrm{n}=10)$. Values marked with the different letters are statistically significantly different $(P \leq 0.05)$ 


\section{Discussion}

Exposure to $\mathrm{O}_{3}$ stresses and pathogen infection induce a rapid accumulation of reactive oxygen species (ROS) in plant tissues. In non-stressed plant tissues enzymatic and nonenzymatic antioxidants are able to neutralize the harmful effects of ROS (Barna et al. 2012). If the abiotic or biotic stress is persistent and too severe, the antioxidants cannot neutralize the overproduction of ROS which leads to cell death and necrosis development. ROS-mediated death of plant tissues can increase or decrease susceptibility to pathogens (Shetty et al. 2008). Response of $\mathrm{O}_{3}$ pretreated crops to pathogen is dependent on type of pathogen (necrotrophic, hemibiotrophic or biotrophic), $\mathrm{O}_{3}$ concentration and the crops growth stage (Mikkelsen et al. 2015). In the present study enhancement in susceptibility of $\mathrm{O}_{3}$ predisposed wheat to $B$. sorokiniana, a hemibiotrophic pathogen was observed. This observation confirms the Tiedemann (1992) reports that susceptibility of wheat to Septoria nodorum and B. sorokiniana after $\mathrm{O}_{3}$ exposure increased. Mikkelsen et al. (2015) also reported increased and decreased infection by the hemibiotrophic spot blotch fungus and biotrophic powdery mildew fungus, respectively, under elevated $\mathrm{O}_{3}$, compared to ambient conditions, implying that $\mathrm{O}_{3-}$ induced changes in disease severity could be linked to the trophic lifestyle of the pathogens.

In plants, PR proteins prevent various pathogen invasion. Among these PR proteins chitinase and $\beta$-1,3-glucanase are two important hydrolytic enzymes play main role of defense reaction against fungal pathogen by degrading cell wall chitin (Ebrahim et al. 2011). In our study $\mathrm{O}_{3}$ pretreated wheat plants exhibited reduction in PR protein content and chitinase activity as compared to control. This is contrary to previous studies where increase of PR proteins like chitinase and $\beta$-1-3-glucanase is reported in different crops on $\mathrm{O}_{3}$ stress exposure (Thalmair et al. 1996). This can be related to variation in $\mathrm{O}_{3}$ sensitivity of different cultivars. For example, near ambient ozone exposure induced $\beta-1,3-$ glucanase (PR-2) activity 22-fold in the $\mathrm{O}_{3}$ tolerant tobacco line Bel B while in $\mathrm{O}_{3}$ sensitive line Bel W3 only a fourfold-increase in $\beta$-1,3-glucanase activity (Schraudner et al. 1994).

In present study it was observed that different levels of antioxidants exhibiting significant inhibitory effect against Bipolaris indicate that antioxidants may be acting as antimicrobial compounds. These observations were in agreement with Cowan (1999) explained that antioxidants as plant product inhibit microbes growth by enzyme inhibition mechanism.

$\mathrm{O}_{3}$ stress mitigating capacity of the three antioxidants (AA, Q, T) used in present study exogenously has not been reported in literature yet. The results shows that exogenous antioxidants application to wheat plants, inhibited growth of Bipolaris on them and enhanced synthesis of PR protein and chitinase. Our findings are in line with Didyk and Blum (2011), reported exogenous application of antioxidants limits foliar necrosis, biomass reduction and alteration of metabolism caused by $\mathrm{O}_{3}$ stress. Querictin and tagetes leaf extract reduced foliar injury by $10-13 \%$ and $14 \%$, respectively, in Trifolium. subterraneum exposed to ambient $\mathrm{O}_{3}$ level for 28 days (Didyk and Blum 2011). Ascorbic acid application reduced the visible leaf injury by $50-89 \%$ and $100 \%$ in $45-55$ ppb and $0-250$ 
ppb $\mathrm{O}_{3}$ exposed Nicotiana tabaccum (Chen and Gallie 2005). In literature it has been reported that application of exogenous ascorbic acid enhances plant tolerance to pathogens because of activation of general defense gene signaling network (Conklin and Barth 2004). However, Rice-Evans et al. (1997) reported that under in vitro conditions quercetin (flavonoids) was more effective antioxidant than ascorbic acid.

Results of the study indicate that $\mathrm{O}_{3}$ concentration and wheat susceptibility to Bipolaris sorokiniana are positively correlated. Antioxidants besides their $\mathrm{O}_{3}$ stress mitigating effects also retards growth of Bipolaris through enhancing synthesis of defense compounds. More studies need to carry out to quantify the contribution of exogenously applied antioxidants in antimicrobial activity and strengthening of defense mechanism of plants compounds and activity. Our study suggests to prevent losses in wheat productivity due to synergistic effect of $\mathrm{O}_{3}$ and hemibiotrophic pathogens proper package of agriculture practices for using antioxidants need to be developed.

\section{Acknowledgement}

Financial support from the Indian Council for Agricultural Research to Indian Agriculture Research Institute is gratefully acknowledged.

\section{References}

Barna, B., Fodor, J., Harrach, B.D., Pogány, M., Király, Z. 2012. The Janus face of reactive oxygen species in resistance and susceptibility of plants to necrotrophic and biotrophic pathogens. Plant Physiol. Biochem. 59:37-43.

Chen, Z., Gallie, D. 2005. Increasing tolerance to ozone by elevating foliar ascorbic acid confers greater protection against ozone than increasing avoidance. Plant Physiol. 138:1673-1689.

Chowdhury, A.K., Singh, G., Tyagi, B.S., Ojha, A., Dhar, T., Bhattacharya, P.M. 2013. Spot blotch disease of wheat-a new thrust area for sustaining productivity. J. of Wheat Res. 5:1-11.

Conklin, P.L., Barth, C. 2004. Ascorbic acid, a familiar small molecule intertwined in the response of plants to ozone pathogens, and the onset of senescence. Plant Cell Environ. 27:959-970.

Cowan, M.M. 1999. Plant products as antimicrobial agents. Clin. Microbiol. Rev. 12:564-582.

Didyk, N.P., Blum, O.B. 2011. Natural antioxidants of plant origin against ozone damage of sensitive crops. Acta Physiol Plant. 33:25-34

Ebrahim, S., Usha, K., Singh, B. 2011. Pathogenesis related (PR) proteins in plant defense mechanism. In: Mendez-Vilas, A. (ed.), Science against Microbial Pathogens: Communicating Current Research and Technological Advances. Formatex Microbiology Series. No. 3, 1, pp. 1043-1054.

Elad, Y., Pertot, I. 2014. Climate change impacts on plant pathogens and plant diseases. J. Crop Improv. 28:99-139.

Fuhrer, J. 2009. Ozone risk for crops and pastures in present and future climates. Naturwissenschaften 96:173194.

Ghude, S.D., Jena, C., Chate, D.M., Beig, G., Pfister, G.G., Kumar, R., Ramanathan, V. 2014. Reductions in India's crop yield due to ozone. Geophys. Res. Lett. 41:5685-5691.

Holland, M., Kinghorn, S., Emberson, L., Cinderby, S., Ashmore, M., Mills., G., Harmens, H., 2006. Development of a framework for probabilistic assessment of the economic losses caused by ozone damage to crops in Europe. CEH Project No. CO2309, New report to U.K. Department of Environment, Food and Rural Affairs under Contract 1/2/170-1/3/205.

IPCC 2013. Climate change 2013: The physical science basis. In: Stocker, T.F., Qin, D., Plattner, G.K., Tignor, M., Allen, S.K., Boschung, J., Nauels, A., Xia, Y., Bex, V., Midgley, P.M. (eds.), Contribution of Working 
Group I to the Fifth Assessment Report of the Intergovernmental Panel on Climate Change. Cambridge University Press. Cambridge, UK and New York, NY, USA. 1535 p.

Manning, W.J., von Tiedemann, A. 1995. Climate change: potential effects of increased atmospheric carbon dioxide $\left(\mathrm{CO}_{2}\right)$, ozone $\left(\mathrm{O}_{3}\right)$, and ultraviolet B (UVB) radiation on plant diseases. Environ. Pollut. 88:219245.

Mina, U., Kumar, P., Varshney, C.K. 2010. Response of different growth stages of potato (Solanum tuberosum) to ozone stress. Phyton. 49:253-266.

Mikkelsen, B.L., Jørgensen, R.B., Lyngkjær, M.F. 2015. Complex interplay of future climate levels of $\mathrm{CO}_{2}$, ozone and temperature on susceptibility to fungal diseases in barley. Plant Pathol. 64:319-327.

Morgan, W.T.J., Elson, L.A. 1934. A colorimetric method for the determination of N-acetylglucosamine and $\mathrm{N}$-acetylchrondrosamine. Biochemical J. 28:988-995.

Puckette, M.C., Tang, Y., Mahalingam, R. 2008. Transcriptomic changes induced by acute ozone in resistant and sensitive Medicago truncatula accessions. BMC Plant Biol. 8:46.

Rice-Evans, C.A., Miller, N.J., Paganga, G. 1997. Antioxidant properties of phenolic compounds. Trends Plant Sci. 2:152-159.

Saari, E.E. 1998. Leaf blight diseases and associated soil borne fungal pathogens of wheat in south and southeast Asia. In: Duveiller, E., Dubin, H.J., Reeves, J., McNab, A. (eds), Helminthosporium Blights of Wheat: Spot Blotch and Tan Spot. CIMMYT, Mexico D.F., pp. 37-51.

Schraudner, M., Graf, U., Langebartels, C., Sandermann, H. 1994. Ambient ozone can induce plant defence reactions in tobacco. Proc. of the Royal Society of Edinburgh. Section B. Biological Sciences 102:55-61.

Shetty, N.P., Jørgensen, H.J.L., Jensen, J.D., Collinge, D.B., Shetty, H.S. 2008. Roles of reactive oxygen species in interactions between plants and pathogens. Eur. J. Plant Pathol. 121:267-280.

Thalmair, M., Bauw, G., Thiel, S., Döhring, T., Langebartels, C., Sandermann, H., Jr. 1996. Ozone and ultraviolet $\mathrm{B}$ effects on the defense-related proteins $\beta$-1,3-glucanase and chitinase in tobacco. J. Plant Physiol. 148:222-228.

Tiedemann, A.V. 1992. Ozone effects on fungal leaf diseases of wheat in relation to epidemiology. I. Necrotrophic pathogens. J. Phytopath. 134:177-186. 